\title{
ECCLESIASTICAL AND THEOLOGICAL ASPECTS OF THE CORONATION ACTS OF THE POLISH KINGS IN THE MIDDLE AGES. AN OUTLINE
}

\begin{abstract}
The coronation ceremonial of the Polish kings reflects the medieval union of the Church and state. The coronation was, therefore, not only a state ceremony but also an ecclesiastical one. It was performed by the archbishop in the cathedral in the presence of the assembled Church and through the coronation the new ruler was involved in the mission of the Church. It should also be noted that the formulary used during the coronation was built on theological foundations. Thanks to the coronation, which made the king God's anointed, the ruler gained a special position in the state and the Church.
\end{abstract}

Keywords: Polish kings; coronation; state and Church; medieval doctrine of lordship

It was commonly believed that the coronation of the king was only a state act and was intended to establish a new ruler. The most important role was assigned to placing the crown on the head of the new monarch and delivering other royal insignia to him. This is how it works in pop culture, including historical films. However, this matter is not so trivial. The coronation act carried deep meaning, most often omitted. Although the coronation ceremony of the Polish rulers has already been analysed in Polish historiography ${ }^{1}$, the ideological overtones of this act were barely mentioned. Hence, we would like to focus on an ecclesiastical

* Ks. Włodzimierz Bielak - Dr habil. Church history, Associate Professor, the John Paul II Catholic University of Lublin;

e-mail: wlodzimierz.bielak@kul.pl

https://orcid.org/0000-0002-3883-5615

${ }^{1}$ E.g. S. Kutrzeba, Źródła polskiego ceremoniału koronacyjnego, „Przegląd Historyczny”, 12 (1911) no. 1, pp . 71-83, no. 2, pp. 149-164, no. 3, pp. 285-307; S. Truchim, Koronacje polskich królów elekcyjnych, Poznań 1931; M. Rożek, Polskie koronacje i korony, Kraków 1987; D. Milewski, Koronacja Augusta II Mocnego na króla Polski, „Saeculum Christianum”, 10 (2003) no. 1, pp. 81-99. 
dimension and theological content of the coronation acts, the issues to which researchers pay little attention.

At the beginning of the fourth century after Christ, the state and the Church began building a close relationship. This process was initiated by the Edict of Toleration (311), issued by the emperor Galerius (293-311). Constantine the Great (306-337), following the example of his predecessors, probably wanted to make Christianity a religion that would unify the Roman Empire. As a consequence, Christianity, as early as the time of Theodosius the Great, gained the rank of the official religion of the Empire, and the Church gained a high position in the structures of the state. Christian emperors became the de facto heads of the Church, and this state of affairs continued in Byzantium until the fall of this empire (1453). In the West, the situation became complicated in the fifth century due to the migration of people. The imperial power in this part of Europe became merely nominal, and the papacy rose to the rank of the highest moral authority and the centre of leadership. Problems arose in the late eighth century when Charles the Great strove to restore the empire in the West, following the example of the former Roman emperors and the Byzantine basileus. In contrast to the Eastern Church, the Latin Church, represented by the Pope, refused to submit to imperial authority. The papacy, accustomed to its position during the migration of people, was aware of its rank and social position. Crowning unexpectedly Charles as emperor (provided Einhard can be trusted) ${ }^{2}$, Pope Leo III made him understand that imperial power came from God and was provided by the hands of the Church. This was a harbinger of a later dispute between the empire and the papacy over supremacy. This conflict is well known in historiography and therefore there is no need to explain it here. One thing worth mentioning is the fact that the development of the medieval Christianitas $^{3}$ and medieval power structures based on two pillars, namely the papacy and the empire, was parallel to the dispute mentioned above. This medieval nature of power was also reflected in the coronation records of the Polish kings, which are of interest to us.

The oldest well-known coronation ceremonial existed as early as the tenth century. It was included, at an unknown time, in the Ordo Romanus, which was produced in the time of Gregory the Great. Perhaps it was used for the coronation of the first Polish kings: Bolesław the Brave, Mieszko II and Bolesław the Bold. As far as native liturgical books are concerned, the earliest coronation rites (which resembled Roman ceremonies) can be found in one of the codes of the Gniezno chapter dated from the twelfth century. The coronations of Przemysł II (1295) and Wenceslaus II (1300) could have been based on this formula ${ }^{4}$. Other ordo coronandi, slightly changed in relation to that of the thirteenth century, were produced in the fourteenth, fifteenth, sixteenth and eighteenth centuries ${ }^{5}$.

Permanent elements of the coronation rites were as follows: the preparation

\footnotetext{
${ }^{2}$ Einhard, Życie Karola Wielkiego, ed. J. Parandowski, Warszawa 1950, p. 52.

${ }^{3}$ Bishop Grzegorz Ryś presented a good definition of this term: „Christianitas is Medieval Europe where christianity was the primary point of reference for the description of one's identity" (https://www.tolerancja.pl/?christianitas-wywiad-z-ks.-prof.-grzegorzem-rysiem,243).

${ }^{4}$ Kutrzeba, Źródła polskiego ceremoniału koronacyjnego, pp. 71-83.

${ }^{5}$ Ordo coronandi regis Poloniae, ed. S. Kutrzeba, „Archiwum Komisji Historycznej”, 11 (1909-1913) p. 133 ff.
} 
of the king in his chamber, the solemn entrance of the king into the cathedral, the singing of the litany to the saints during which the king was lying prostrate in front of the altar, intercessory prayers for the blessing of the king and God's help in fulfilling the ruler's duties, the anointing of the king with chrism oil, the delivery of the insignia of power (after presenting each one, the appropriate prayer was said), an oath made by the king, the bestowing of the kiss of peace, the singing of Te Deum laudamus and Holy Mass according to the appropriate formulary 6 . Some modifications were introduced over time, but the content of the prayers and the most important gestures well known from the thirteenth-century Ordo coronandi were present throughout the Middle Ages.

The first and most obvious sign of the ecclesiastical dimension of the royal coronation was the fact that it was performed in the cathedral by the highest hierarch of the Polish Church - the archbishop of Gniezno. He maintained a close liaison with the Pope, who was already regarded as vicarius filii Dei at that time ${ }^{7}$. If one assumes that the coronations of Bolesław the Brave, Mieszko II and Bolesław the Bold were based on the Ordo Romanus, it can be inferred that all medieval coronations of the Piast, Angevin and Jagiellonian kings in Poland were performed by the archbishops of Gniezno. This is confirmed by the Polish Ordo coronandi, in which the most important moments of the coronation are reserved to the archbishop ${ }^{8}$. Although the coronation was conducted in Krakow from the coronation of Władysław Łokietek onwards, the participation of the archbishops of Gniezno during this ceremony was indispensable.

The second element indicating the ecclesiastical nature of the coronation is its form of a liturgical rite with the use of appropriate prayers, blessings and solemn gestures related to the anointing and delivering of the royal insignia. The oldest preserved Ordo coronandi in Poland, used in the thirteenth century, provided for a Holy Mass for the newly crowned ruler with special prayers. It was also recommended for the coronation to be performed on Sunday ${ }^{9}$. From the sixteenth century onwards, Holy Mass became an inherent part of the coronation, which was conducted during $\mathrm{it}^{10}$. The coronation was therefore not only a state event but also a church one, celebrated in the church and by the Church.

The coronation linked the king to the mission of the Church. First of all, he was treated as a human being. The ruler was a member of the Church and should follow the path of salvation. The most important thing is faith and through it all those who are called by God and anointed conquer kingdoms ${ }^{11}$. Therefore, the

\footnotetext{
${ }^{6}$ Ibidem, passim.

${ }^{7}$ This title appears in the so-called Donatio Constantini, one of the most important texts forming a basis for the idea of the papal supremacy. J. Soszyński, Donacja Konstantyna. Tekst taciński i przekład polski, „Przegląd Tomistyczny”, 17 (2011) p. 18.

${ }^{8}$ Ordo coronandi regis Poloniae, passim.

9 „Tunc episcopus metropolitanus missam celebret plena processione. Sequitur ordo missarum, si in feria evenerit, sed melius et honorabilius est in die dominica" (Ordo coronandi regis Poloniae saeculi XIII, p. 154. The same Ordo coronandi regis Poloniae saeculi XIV, p. 160).

${ }^{10}$ Ordo coronandi regis Poloniae saeculi XVI, pp. 174-193.

${ }^{11}$ Ordo coronandi regis Poloniae saeculi XIII, p. 150,
} 
king should, above all else, believe in God and serve him diligently ${ }^{12}$. The king was also reminded of the following qualities that a good ruler ought to have: $f$ delitas, mansuetudo, fortitudo, sapientia and humilitas. The example of biblical figures was used here ${ }^{13}$. The king's faith should be reflected in his governing style: "Corona eum corona iustitie et pietatis"14. It ought to be noted that the noun Pietas has quite a broad meaning, apart from God's love, it also means the love of homeland, a sense of duty, commitment to family, charity and mercy. In short, the king's traits of a good Christian should have an impact on the way he governs his people, who are at the same time God's people and part of the Church.

At the coronation, the king accepted some responsibilities towards the Church. His duty was primarily to defend the Church. It was not a new idea, because Constantine the Great would say about himself ,You are bishops in all which is interior to the Church, and I am a bishop for all the external affairs of the Church"15, and Charles the Great went even further - he considered himself the real head of the Church in all matters, about which he wrote to Pope Leo III in $795^{16}$. Charles's idea of the emperor or king was impossible to implement in the later Middle Ages; it was Constantine's vision that was more easily adopted at the time. According to it, duties were divided into intra-church ones - assigned to the bishop - and those supporting the mission of the Church - intended for the ruler. The king's task was therefore to ensure the Church the freedom to conduct a pastoral and evangelizing mission, to defend Christians, to lead the wrongdoers to the path of justice and to fight heresy. Like the Church, the king should take special care of the weakest, oppose injustice, and punish injustice ${ }^{17}$.

The link between the mission of the Church and an ecclesiastical aspect of the royal power was symbolically emphasized at the coronation by the custom of dressing the king in the robes usually used by the bishop: sandals, amice, alb, stole, maniple, dalmatic and cope ${ }^{18}$. It can be said that both the bishop, who was

${ }^{12}$,ut ex toto corde et tota mente credens in te tibi deserviat” (Ordo coronandi regis Poloniae saeculi XIII, p. 151).

${ }^{13}$ Ordo coronandi regis Poloniae saeculi XIII, p. 150.

${ }_{14}^{14}$ Ordo coronandi regis Poloniae saeculi XIII, p. 151; Ordo coronandi regis Poloniae saeculi XV, pp. 168, 172; Ordo coronandi regis Poloniae saeculi XVI, pp. 181, 190.

${ }^{15}$ Euzebiusz z Cezarei, Życie Konstantyna, IV, 24, translated by T. Wnętrzak, p. 221.

16 „Nostrum est: secundum auxilium divinae pietatis sanctam undique Christi ecclesiam ab incursu paganorum et ab infidelium devastatione armis defendere foris, et intus catholicae fidei agnitione munire" (Monumenta Germaniae Historica, Epistolarum tomus IV, Epistolae carolini aevi, vol. 2, Berolini 1895, no. 93, p. 137).

17 „Fac eum Domine beatum esse et victorem de inimicis suis. (...) ut (...) sanctam tuam ecclesiam defendat et sublimet populumque a te sibi commissum iuste regat, nullis insidiantibus malis eum in iusticiam vertet" (Ordo coronandi regis Poloniae saeculi XIV, p. 158; Ordo coronandi regis Poloniae saeculi $X V$, p. 168); ,ut in hoc per eundem vim equitatis exerceas, molem iniquitatis potenter destruas et sanctam Dei ecclesiam eiusque fideles propugnes ac protegas nec minus sub fide falsos quam christiani nominis hostes execres et destruas, viduas ac pupillos clementer adiuves ac defendas, desolata restaures, restaurata conservas, ulciscaris iniusta, confirmes bene disposita" (Ordo coronandi regis Poloniae saeculi XIII, p.152; Ordo coronandi regis Poloniae saeculi XIV, p. 159; Ordo coronandi regis Poloniae saeculi XV, p. 171).

${ }^{18}$ Ordo coronandi regis Poloniae saeculi XV, pp. 161-162; this rite is confirmed by Jan Długosz in the description of the coronation of Władysław Warneńczyk (Jana Dlugosza Roczniki czyli Kroni- 
the leader of the Church, and the king, who ruled Christians, ought to cooperate and complement each other in establishing the kingdom of Christ on earth. They both used different means and methods which were at their disposal, but their religious goal was the same. In this way, efforts were made to implement one of the main principles of the medieval order and medieval christianitas.

The coronation rites had obviously a theological foundation. First of all, it should be mentioned that the participation of the Church in the coronation resulted from the idea that all power comes from God as well as from the belief in the primacy of the spiritual authority and in the Church as the only intermediary between God and the world. According to the teaching of canonists, it was the pope who was the head of the Church and he exercised full authority, even if the emphasis was sometimes shifted to the Church with which the pope had to be in communion $^{19}$. It is not surprising that the reminders of the divine provenance of the authority that the newly appointed king received through the hands of the Church appeared a number of times during the coronation ${ }^{20}$. In this way, the Church strove to attach the monarch to itself.

Undoubtedly, the most important moment in the king's coronation liturgy was not placing the crown upon the monarch's head, but anointing him with the chrism oil, which the Church used mainly for baptism and priestly ordination. It was at this point that the king became king. The king's anointment is a centuries-old tradition, dating back to the biblical times of the Old Testament. Only people chosen by God and assigned to the most important tasks (e.g. kings and prophets) were anointed $^{21}$. In the New Testament, Jesus Christ was anointed with the oil of joy and the Holy Spirit. The anointing of the king during the coronation was a sign given to the assembled people that this was a man called by God and destined by him to rule Christians and that he was equal to the ancient kings and prophets whom he now joins. The king was reminded that the power he was granted was a gift from God ${ }^{22}$.

ki Stawnego Królestwa Polskiego, vol. 11-12: 1431-1444, p. 154). An explanation of the symbolism of the robes can be found, for example, in the work by Mikołaj of Błonia, Tractatus sacerdotalis de sacramentis deque divinis officiis et eorum administrationibus. [Impressus Cracoviae in edibus ... Joannis Haller Anno 1519], fo. 49v.

${ }^{19}$ These issues are explained by S. Swieżawski, Eklezjologia późnośredniowieczna na rozdrożu, Kraków 1990, p. 71 ff.

${ }^{20}$ „Benedic, Domine, (...) qui regna omnium moderaris a seculo”; „Domine (...) imperator angelorum, rex regnancium, dominusque dominancium" (Ordo coronandi regis Poloniae saeculi XIII, p. 149; Ordo coronandi regis Poloniae saeculi XIV, p. 156, Ordo coronandi regis Poloniae saeculi XV, p.165, Ordo coronandi regis Poloniae saeculi XVI, pp. 179, 187-188); „Benedicat tibi Dominus, custodiat te et sicut te voluit super populum suum esse regem..." (Ordo coronandi regis Poloniae saeculi XIII, p. 153; Ordo coronandi regis Poloniae saeculi XIV, p. 160; Ordo coronandi regis Poloniae saeculi XV, p. 173); „...omnis potestas a Domino Deo est...”(Ordo coronandi regis Poloniae saeculi XVIII, p. 198).

${ }^{21}$ Exodus 30, 22-33.

${ }^{22}$ „Ungantur manus iste de oleo sanctifico, unde uncti fuerunt reges et prophete, et sicut unxit Samuel David in regem, ut sis benedictus et constituus rex in regno isto super populum istum, quem Dominus Deus tuus dedit ad regendum et gubernandum" (Ordo coronandi regis Poloniae saeculi XIII, p. 150, Ordo coronandi regis Poloniae saeculi XIV, p. 157, Ordo coronandi regis Poloniae 
There is also a note explaining that the anointing of the king's head with oil means anointing him with the Holy Spirit, performed by the Son of God; and the Holy Spirit penetrated the mind and heart of the monarch ${ }^{23}$, thus allowing him to perform the tasks entrusted to him. There is an analogy here with the descent of the Holy Spirit on Jesus just before he began his public ministry ${ }^{24}$. Therefore, the king, who was anointed with the Holy Spirit, participated in the mission of Christ.

$$
* * * * *
$$

The discussion presented above shows that the coronation rite placed the king in a unique position in a Christian society. It made the ruler God's anointed, the one under God's protection. As a result, the monarch enjoyed due respect and honour. Not only did he play a political role, but he also took part in the mission of the Church, and ultimately of Christ himself. This gave a special dimension to the civilization of Western Europe in the golden period of the Middle Ages marked by the idea of christianitas.

Translated by Aneta Kiper

\section{REFERENCES / BIBLIOGRAFIA}

\section{Sources}

Einhard, Życie Karola Wielkiego, ed. J. Parandowski, Warszawa 1950.

Euzebiusz z Cezarei, Życie Konstantyna, translated by T. Wnętrzak, Kraków

Nicolaus de Blonie, Tractatus sacerdotalis de sacramentis deque divinis officiis et eorum administrationibus. [Impressus Cracoviae in edibus ... Joannis Haller Anno 1519].

Ordo coronandi regis Poloniae, ed. S. Kutrzeba, „Archiwum Komisji Historycznej”, 11 (1909-1913) p. 133-216.

Soszyński J., Donacja Konstantyna. Tekst łaciński i przekład polski, „Przegląd Tomistyczny”, 17 (2011) p. 7-27.

\section{Literature}

Kutrzeba S., Źródła polskiego ceremoniału koronacyjnego, „Przegląd Historyczny”, 12 (1911) no. 1, pp. 71-83, no. 2, pp. 149-164, no. 3, pp. 285-307;

Milewski D., Koronacja Augusta II Mocnego na króla Polski, „Saeculum Christianum”, 10 (2003) no. 1, pp. 81-99.

Rożek M., Polskie koronacje i korony, Kraków 1987.

Swieżawski S., Eklezjologia późnośredniowieczna na rozdrożu, Kraków 1990.

Truchim S., Koronacje polskich królów elekcyjnych, Poznań 1931.

saeculi XV, p. 169). Also Ordo coronandi regis Poloniae saeculi XIII, p. 150, Ordo coronandi regis Poloniae saeculi XIV, p. 157, Ordo coronandi regis Poloniae saeculi XV, pp. 167, 168.

${ }^{23}$ „Deus Dei Filius Jhesus Christus dominus noster, qui a patre oleo exultationis est unctus pre participibus suis, ipse per presentem sacri unguiminis infusionem Spiritus paracliti super caput tuum infundat benedictionem eandemque usque ad interiora cordis tui penetrare faciat" (Ordo coronandi regis Poloniae saeculi XIII, p. 151, Ordo coronandi regis Poloniae saeculi XVI, p. 180, Ordo coronandi regis Poloniae saeculi XVIII, p. 202).

${ }^{24}$ Matthew 3:16; Mark 1:10; Luke 3:21-22. 


\section{KOŚCIELNE I TEOLOGICZNE ASPEKTY AKT KORONACYJNYCH KRÓLÓW POLSKICH W ŚREDNIOWIECZU}

\section{Streszczenie}

Ceremoniał koronacji królów polskich wpisuje się w średniowieczny związek Kościoła i państwa. Koronacja miała więc wydźwięk nie tylko państwowy, lecz także kościelny - była udzielana przez arcybiskupa w katedrze, wobec zgromadzonego Kościoła. W pewien sposób koronacja włączała nowego władcę w misję Kościoła. Używany podczas koronacji formularz zawierał podbudowę teologiczną dokonywanego aktu. Koronacja, czyniąca z króla pomazańca Bożego, dawała władcy szczególną pozycję w państwie i w Kościele.

Słowa kluczowe: królowie Polski; koronacja; państwo i Kościół, średniowieczna doktryna panowania 